\title{
Cambrian age Welsh Slate: A Global Heritage Stone Resource from the United Kingdom
}

\author{
${ }^{1}$ Slate and Stone Consultants, Ceunant, Caenarfon, Gwynedd LL55 4SA, United Kingdom. Corresponding author E-mail: terry@ slateroof.co.uk \\ ${ }^{2}$ Amgueddfa Cymru -National Museum Wales, Cardiff CF10 3NP, United Kingdom. E-mail: dafydd.roberts@museumwales.ac.uk \\ ${ }^{3}$ British Geological Survey, Keyworth, Nottingham, NG12 5GG, United Kingdom. E-mail: g.lott@bgs.ac.uk \\ ${ }^{4}$ Amgueddfa Cymru -National Museum Wales, The National Slate Museum, Llanberis, Gwynedd, LL55 4TY United Kingdom. \\ E-mail: jana.horak@museumwales.ac.uk
}

(Received: 04/12/14; Accepted: 01/10/2015)

DOI:10.18814/epiiugs/2016/v39i1/89236

Slate from the Cambrian succession of North Wales is a well-known source of building products from the United Kingdom and is here advocated as a suitable "Global Heritage Stone Resource". Its first recorded use was in the Roman period in Wales, and subsequently from the sixteenth century throughout the British Isles. During the 16th and 17th centuries several small companies worked the slate belt from Bethesda to the Nantlle valley but in the mid-18th these were gradually taken over or amalgamated and three large operations came to dominate the industry: Penrhyn, Dinorwic, and the Moel Tryfan to Dorothea group of quarries. From the late eighteenth century production expanded rapidly supplying markets worldwide especially to northern Europe and the British colonies. Slate has been used in all its forms but most notably as roofing slates in the construction of buildings at all levels in society and for buildings of the highest historical and architectural importance. Modernisation of the industry has enabled Cambrian Welsh Slate to continue to be quarried today in an environmentally sensitive manner by Welsh Slate Ltd.

\section{Introduction}

The purpose of this paper is to advance the proposal that slate from the Cambrian succession of North Wales (Fig 1), subsequently referred to as Cambrian Welsh Slate, be accorded the internationally recognised designation of Global Heritage Stone Resource (GHSR) by consideration and discussion of the heritage and geological characteristics of this lithology. Cambrian Welsh Slate is a dimension stone from the United Kingdom with worldwide use and recognition.

The aim of the GHSR designation has been reviewed by Cooper (2008, 2010a-c). Cooper (2008) proposed that GHSR designation should be considered valuable because it will create increased awareness of natural stone, recognise its widespread utilisation in human culture, and promote its modern position as a sustainable building material. The GHSR will also enhance professional recognition and understanding of natural stone as a resource amongst geologists, engineers, architects and building conservationists, the principal professional groups that work with dimension stone. In addition, it is believed that GHSR designation will offer a formal mechanism for characterising natural stone material, for professional purposes and place it, in an internationally accepted context. In general, it will also assist in promoting international co-operation on the research and utilisation of natural stone.

With this perspective, the proposed GHSR designation is being supported via the website www.globalheritagestone.com that was established in August 2010.

\section{Criteria for GHSR recognition}

The defining characteristics of a GHSR have been published as evolving Draft Statutes in the Global Heritage Stone (GHS) Circular 1 (May 2009) and GHS Circular 2 (September 2010), and have been circulated to interested experts and offered for public comment at www.globalheritagestone.org.

It has been generally recognised that a GHSR nominee must have:

- a cultural history encompassing a significant period - at least 50 years has been suggested;

- been utilised in significant works;

- wide geographic use, extending if possible to numerous countries.

Contemporary quarrying and hence the ongoing availability of a GHSR for future construction can enhance the status of a GHSR and hence is also beneficial.

\section{GHSR nomination and citation by the Welsh Stone Forum}

The GHSR nomination of Cambrian Welsh Slate is proposed by the Welsh Stone Forum and is supported by Gwynedd County Council, Snowdonia National Park Authority; Welsh Slate Ltd. and the Stone Roofing Association. The Welsh Stone Forum is a voluntary not-for- 


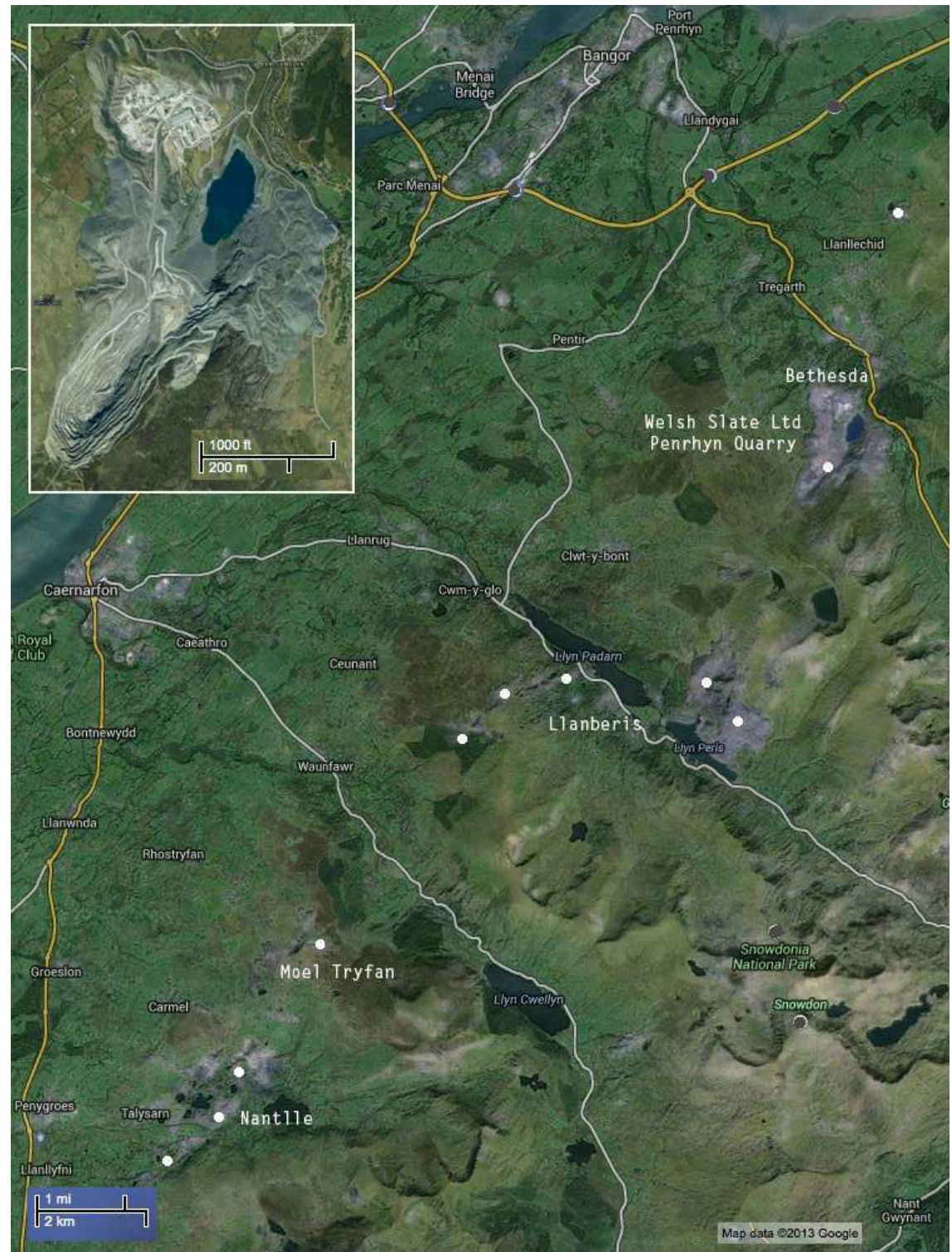

Figure 1. The Cambrian slate belt in Gwynedd extends over $14 \mathrm{~km}$ and was historically quarried in three main areas at Bethesda, Llanberis and from Moel Tryfan to the Nantlle Valley. The currently worked Welsh Slate Ltd quarry at Bethesda is shown inset. (Image Google Maps)

profit organisation that works to support the production and use of Welsh building stone.

\section{Welsh Slate: Introduction}

Slate from the Cambrian, Ordovician and Silurian periods has been exploited in Wales for almost 2000 years. (A separate proposal for GHSR designation for Ordovician slate is to be made later and together with the Cambrian slate will be proposed as constituents of a Global Heritage Stone Province).

This proposal covers metamorphic slate of the Llanberis Slate Formation of North Wales. The protolith to the slate was deposited during the Cambrian Period, with a more closely constrained age provided by the rare occurrence of the trilobites Pseudotops viola, protolenius?, Strenuella? And Serrodiscus? (Howell and Stubblefield, 1950) towards the top of the sequence. This fauna suggests the Formation lies within Series 2, near the boundary of stages 3 and 4 (corresponding to an age of $<520 \mathrm{Ma}$ ) (Rushton and Molyneux, 2011). Metamorphism occurred during the 'Acadian' deformation dated at around $400 \mathrm{Ma}$ [e.g. Evans, 1996]. Green reduction spots within the purple and blue-grey slate are a prominent feature and have been used in strain analysis to determine the nature and mechanism of cleavage formation processes by both early workers (e.g. Sorby, 1853) and more recent studies (e.g. Wood, 1974). Wood (1974) used these strain markers to determine the slate had undergone up to $67 \%$ horizontal shortening and up to $157 \%$ vertical extension during development of the cleavage.

Good quality slate has been attributed the features of an illite crystallinity of less than $0.25 \Delta^{\circ} 2 \theta$ and phyllosilicate-rich domains (Pdomains) 0.5 to $10 \mu \mathrm{m}$ wide and $2-40 \mu \mathrm{m}$ apart (Merriman and Peacor, 1999). Data presented by Merriman (2005) for Cambrian Welsh Slate fall within these criteria.

The slate is widely used throughout the British Isles and worldwide and there is an extensive published literature describing its extraction and use. Notable amongst these publications are North (1925) covering the geological formation and exploitation of Welsh slate, and Pritchard's (1942) economic history of the slate industry. Lindsey (1974) described the commercial development of the industry and Richards has written extensively on the industry, provided a gazetteer of mines and quarries (1991), and an economic and technical history of the industry (2006). Hughes (1995) produced a report for Gwynedd County Council covering the state of the North Wales slate industry at that time and its potential for the future. Additionally there are many books on the history and operations of individual quarries and mines and the culture of the slate communities.

The earliest evidence for the use of Cambrian slate is from archaeological excavations of Roman buildings. Slate was used to roof Segontium Fort (AD74 - 383) at Caernarfon (Wheeler, 1923); diamond pattern roofing slates were discovered at a large Roman settlement near Porthmadog. Roofing slates have been found at other Roman sites as much as 60 miles from the source quarries, at Chester (Roman Deva). However it was not until the 13th century that there is evidence of significant production when slate from the Bangor and Caernarfon districts was used by Edward I to roof the castles at Caernarfon and Conwy (now UNESCO World Heritage sites Castles and Town Walls of King Edward in Gwynedd http://whc.unesco.org/en/list/374). By the 16th century slate had become an important export from Wales to Ireland, shipped from the slate ports of Beaumaris (the port of registry for Bangor) and Caernarfon (Lewis 1927). By the later decades of the 18 th century the Welsh slate industry had expanded to produce approximately 26,000 tons annually. During the next century demand for roofing slates to supply the rapidly expanding industrial towns, together with access to the newly developed canal and rail transport networks, resulted in an increase in production from 100,000 to over 


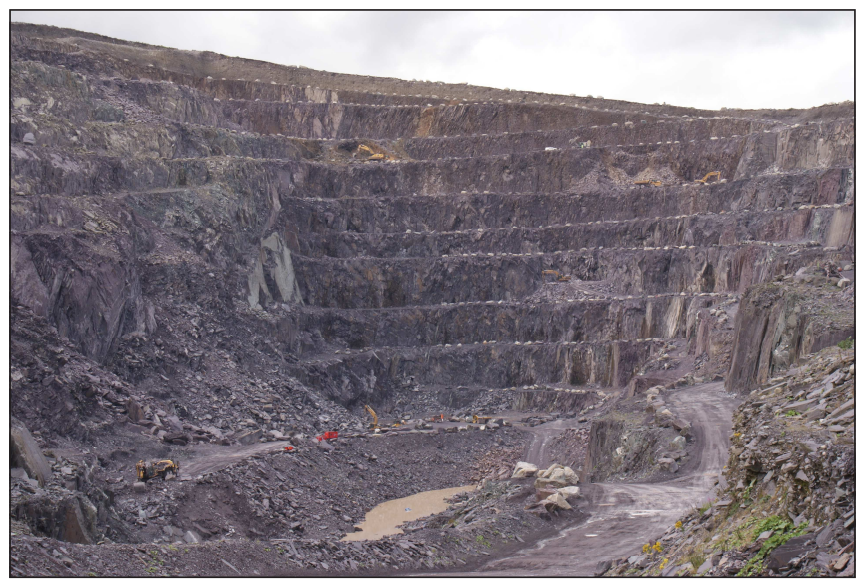

Figure 2. Cambrian slate is currently produced for roofing, architectural and a variety of crushed slate products at Penrhyn Quarry at Bethesda. (Image T Hughes)

450,000 tons a year between 1832 and 1882 , culminating in a peak of 600,000 tons by the end of the 19th century. During the 19th and 20th centuries exports worldwide expanded, notably into northern Europe and the British colonies in North America, South Africa, Australia and New Zealand. From the early twentieth century the industry declined because of competition from other products, particularly from concrete roof tiles, and imports from countries with a lower cost basis. However, the Cambrian slate quarry, Penrhyn (Fig 2), is a substantial operation with current annual production of 1.3 million roofing slates equal to 14,000 tonnes and a number of smaller quarries operate producing roofing slates and reworking tips for aggregates.

Since the 18th century, Welsh slate has been used for roofing and other purposes in buildings of national, historical and architectural significance throughout the British Isles, in Europe and worldwide (Fig 3). A select list is included below. These buildings are usually subject to strict conservation controls and are repaired on a like for like basis. Many are up to 200 years old and are due for repair as a result of failure of their fixings, constituting a substantial future market.

The slate industry of this region and the neighbouring Blaenau Ffestiniog slate mines were quick to adopt industrial innovations firstly using water power and subsequently, steam and electricity. Innovative mining, quarrying and rock processing techniques were adopted or developed which, while some were unique to slate, were often also applicable to other stone industries and were adopted in many other countries - most notably in France and the USA. The locomotiveworked narrow-gauge railway was the distinctive solution evolved by the industry to the problem of transporting the slates from the quarry to navigable water. This was adopted by engineers world-wide from 1870 onwards.

The craft skills of the workforce were also disseminated by emigration of quarrymen to the USA, Australia and other countries especially as a consequence of the strikes and lock-outs from 1874 to 1903.

Its landscape impact is profound and largely intact, creating distinctive quarrying environments, and settlements that are recognised as classic examples of 19th-century industrial/vernacular towns and villages. There has been little redevelopment or reclamation. Some sites have been conserved since the 1970s. (World Heritage Status proposal 27 January 2012)

The slate industry of this region has also played an important part in the history of industrial relations. The North Wales Quarrymen's Union was established in 1874 as a result of growing discontent amongst the quarrymen, particularly the Penrhyn and Dinorwic workers, about pay and working conditions. By May 1874 the Union had grown to a membership of 8,368 but the quarry owners were

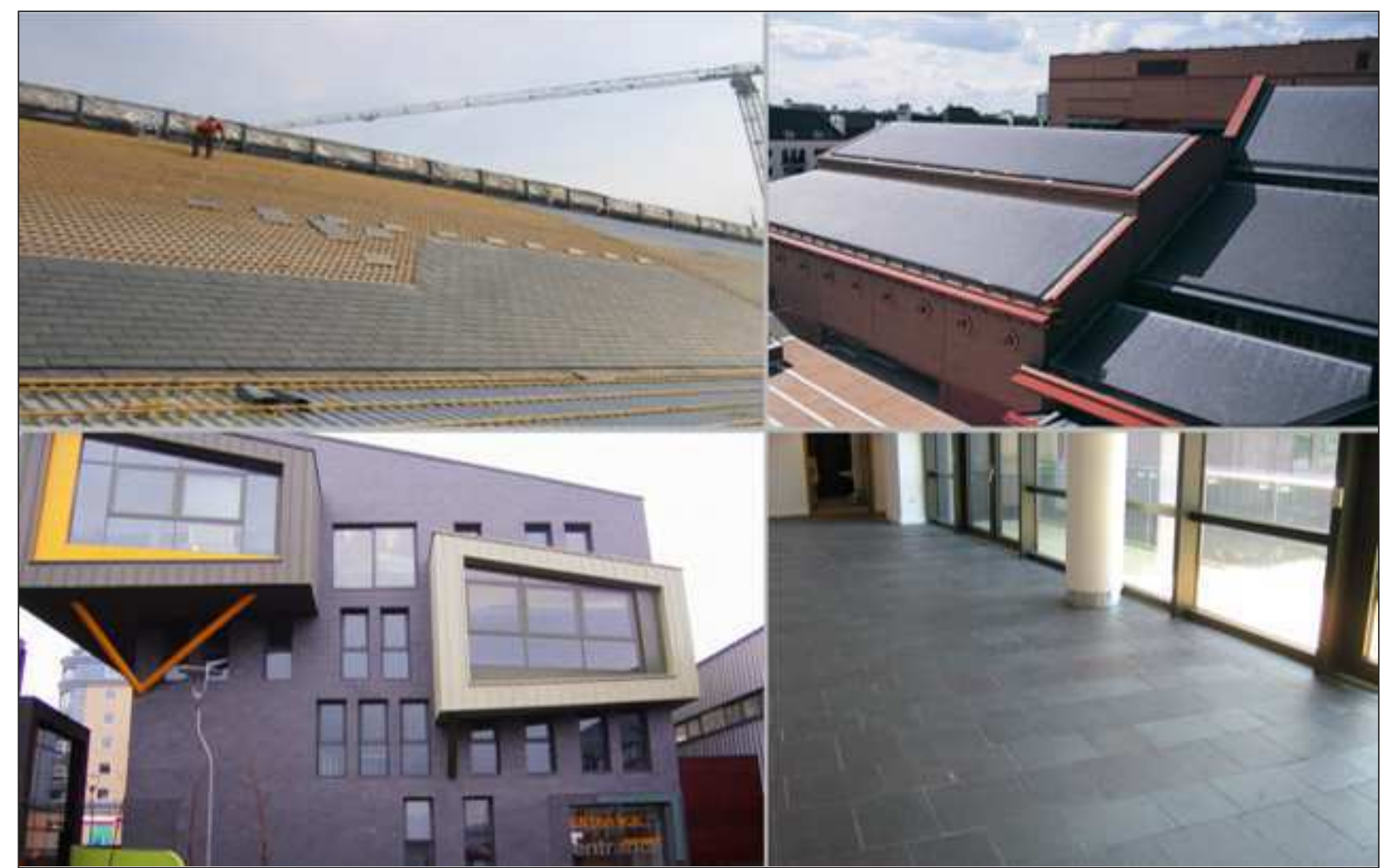

Figure 3. Cambrian Welsh slate is used for roofing and other purposes in buildings of national, historical and architectural significance throughout the British Isles, in Europe and worldwide. (Images T Hughes and Welsh Slate Ltd) 
unwilling to recognise it or enter into negotiations on pay and conditions. This was to become one of the first disputes about who runs a company; the owners or the workers. In June of that year 2,200 quarrymen were locked out of Dinorwic Quarry but after five weeks the managers agreed to recognise the union. This was followed by a similar dispute at the Penrhyn Quarry, the Great Strike of 19001903, one of the longest strikes in British industrial history, which saw the workers defeated by the quarry owners. Men returned to work on Lord Penrhyn's terms.

The Institute of Quarrying which now has branches in Australia, Hong Kong, Malaysia, New Zealand and Southern Africa as well as the UK was hosted by the slate industry at its first meeting (as the Association of Quarry Managers) at Caernarfon in 1917.

The slate quarrying regions produced distinctive cultures but often separated by language and religion. The business functioned through the medium of the Welsh language, making it unique within major capitalised British industries. The workers were almost entirely Welsh speaking and Non-conformist worshippers in their local chapels; the management tended to be monoglot English speakers and Anglican worshippers. Within the quarry there was a strong cultural life based around the 'cabans' where the workers took their breaks and also within the "barracks" for those who lived far away and would stay in the quarry from Monday to Saturday. In the cabans there were regular formal debates on issues of the day such as religious non-conformity and trade unionism. There were also eisteddfodau - competitions for poets and musicians - and each quarry would have its own silver or brass band.

\section{Citation for Welsh Slate (Cambrian)}

For the purpose of GHSR nomination, the HSTG Terms of Reference state that citations shall contain specific information. This is further discussed in Cooper et al. (2013). Consequently in order to nominate Cambrian age Welsh Slate as a GHSR the following definitive details are provided:

Formal Name

Cambrian age Welsh Slate.

Other Names

Penrhyn Slate, Bangor Blue Slate, Dinorwic Slate, Dorothea Slate, Caernarfon Slate, Twll Llwyd Slate plus many others based on local quarry names.

Place of Origin

Gwynedd, Wales, UK

\section{Resource Location}

Bethesda, Llanberis, Moel Tryfan \& Nantlle in the Ogwen to Nantlle valleys Gwynedd, North Wales, UK

\section{Quarrying}

Extensive slate quarrying operations have existed in the region since the 17th century. Quarrying reached a peak of 600,000 tons by the end of the 19th century. Cambrian Welsh Slate is currently worked at Penrhyn quarry; in a small quarry, Twll Llwyd and a number of quarries tips are being reworked to produce aggregates.

Lithostratigraphic Name:

Llanberis Slate Formation

\section{Petrology of Cambrian slate}

Petrology information relating to the Cambrian slates of North Wales within the GHSR, is derived from technical data produced for compliance with BS EN 1232601-2011 and from academic research (e.g. Merriman \& Peacor, 1999). The slate meets all the criteria laid out in BS EN 1232601-2014 (Slate and stone for discontinuous roofing and external cladding). Macroscopically the texture is seen to be homogenous and shows a very well defined planar metamorphic cleavage. It is most typically dark purple in colour equating to Munsell 5R 4/1 (dark reddish grey) (Munsell Soil Colour Charts 2000), but ranges between grey and blue grey and includes two shades of green and a red. Locally the purple slates contain green ellipsoidal spots, or bedding parallel patches, attributed to different oxidations states of the iron content. There is no obvious sedimentary stratification observed within the worked slates, although evidence of original sedimentary bedding is seen within the sequence of the Llanberis Slates Formation more broadly and is represented by the presence of coarser-grained layers.

Thin section examination, up to $\mathrm{x} 400$ magnification under polarising light, reveals a mineralogy dominated by phyllosilicates (up to $5 \%$ by volume) and chlorite ( $25 \%$ by volume). The remaining mineralogy comprises hematite, pyrite and quartz. The pyrite is present as small $(4-40 \mu \mathrm{m})$ individual euhedral crystals, or sub-euhedral clusters. Some of these grains are oxidised, and hematite is visible as disseminated grains along the cleavage fabric. It is this oxidised iron that imparts the distinct purple colour to the slate. As in the macroscopic appearance, healed joints, faults and obvious traces of sedimentary stratification are not observed. The phyllosilicate fabric, using the textural criteria cited in BS EN 123260-1-2011, is defined as being perfectly connected, continuous, and forming a net-like fabric. Formal reporting has determined a density of 59 phyllosilicate layers per mm, with an average thickness of each layer of $10 \mu \mathrm{m}$ and an overall density of $590 \mu \mathrm{m}$ per $1000 \mu \mathrm{m}$ of rock.

The research of Merriman and Peacor (1999) presents the most detailed textural work undertaken on the slates, using SEM analysis, and confirms the optical microscopy observations. They report phyllosilicate layers, which they term 'P-domains', as $0.5-10 \mu \mathrm{m}$ wide separated by 2-40 $\mu \mathrm{m}$ wide Q-domains, comprising non-phyllosilicate minerals typically quartz. Elongation of these Q domains is suggested to produces the 'grain' seen on the surface of some cleavage planes. The metamorphic grade of the slates, determined by the illite crystallinity values, are recorded by a Kubler Index of less than 0.25 $\Delta^{\circ} 2 \theta$, representing epizonal grade. Additional research on the slates include a study by Manning (1975), on the nature of the green 'reduction' spots. The main findings of this were that colour variations present as spots and discontinuous layers were produced by differences in oxidisation states of iron, but not reducing conditions.

$\begin{array}{cc}\begin{array}{c}\text { Chemical composition } \\ \text { Typical ranges }\end{array} & \text { Weight } \% \\ \mathrm{SiO}_{2} & 45-65 \\ \mathrm{Al}_{2} \mathrm{O}_{3} & 11-25 \\ \mathrm{FeO} & 0.5-7 \\ \mathrm{Na}_{2} \mathrm{O} & 1-4 \\ \mathrm{~K}_{2} \mathrm{O} & 1-6 \\ \mathrm{MgO} & 2-7 \\ \mathrm{TiO}_{2} & 1-2 \\ \mathrm{Carbonate}^{*} & <1 \% \\ \text { Non-carbonate carbon* } & 0.7 \%\end{array}$




\section{Geotechnical Properties}

Water absorption*

Density

Compressive Strength

Characteristic flexural strength*

Parallel to grain

Perpendicular to grain

Sulphur dioxide exposure*

Thermal cycle test*

* Tested to EN12326-1 and EN12326-2 Slate and stone for discontinuous roofing and cladding. The test results places the slate in the highest category of the European standard.

\section{Colour and aesthetics}

Purple, blue, blue-grey, green, red.

Natural variability:

Within each colour the slates vary in hue, reflecting slight variations in chemical composition and physical properties. In use there are only slight and slow changes to their colour.

\section{Suitability}

Used for all building applications - roofing, cladding, masonry etc and for decorative items, monumental masonry, letter cut commerative plaques and sculpture. Primary use is roofing.

\section{Stratigraphy}

Cambrian Welsh Slate is a metamorphic rock from the Llanberis Slate Formation.

All of the Cambrian strata in this area have been subject to lowgrade regional metamorphism, which has induced a well-developed slaty cleavage within the fine-grained sediments. It is this regional cleavage (which at Penrhyn quarry is sub-vertical, dipping at about $80^{\circ}$ towards the south-east), which is exploited, enabling the slate to be easily cleaved into thin, but highly durable roofing slates. The slaty cleavage lies sub-parallel to the regional (north-east to southwest) fold axes developed in this area. (GWP Consultants LLP February 2012)

\section{Commercial designations}

Roofing slates and other products from the resource are marketed under their individual quarry names. Current examples include Penrhyn Slate and Twll Llwyd Slate

\section{Vulnerability and Maintenance of Supply}

Currently supply and demand are in balance. There is scope to expand supply. Viability of reserves is dependent on overburden; Cambrian Slate is worked as open quarries and there are adequate reserves for at least fifty years at current rates of production.

\section{Historic Use}

Worldwide. Slate has been exploited in the region for nearly 2000 years. Since the $16^{\text {th }}$ century it has been traded internationally and since the $18^{\text {th }}$ worldwide. Exports have primarily been to northern Europe, former UK colonies, North and South America, Japan, Africa and Oceania - Australia, New Zealand, Hawaii
Buildings with dates of construction and (repair):

Roofing slate unless specified otherwise

$\begin{array}{ll}\text { Austria } & \text { Kunsthistorisches Museum Vienna } 1891 \\ \text { Australia } & \text { St. Pauls College, University of Sydney } 1856 \\ & \text { Glebe Town Hall, Sydney } 1880 \\ & \text { Juniper Hall, Paddington, Sydney } 1824 \\ & \text { National Arts Centre (Darlinghurst Gaol) Sydney } \\ & 1822 \\ & \text { St. James' Anglican Church, Sydney } 1824 \\ & \text { All Hallows Girls School Brisbane Queensland }\end{array}$
1861

Flinders Street Station Melbourne 1909, (2013) Victoria Barracks, Melbourne. 1852 - 1856, (2013)

Customs House, Newcastle, NSW 1874 - 1889

Old Farm, Strawberry Hill, Albany West Australia 1870

Denmark Amalienborg (The Royal House), Copenhagen $1750-1760$

Railway Station, Skodsborg

France Hotel de Ville, Paris

Hawaii Royal Mausoleum

Ireland Trinity College Dublin

Dublin Customs House

Dublin Castle

Church of the Immaculate Conception, Cavan

New Zealand Arts Centre, Christchurch 1882

Sweden The English Church, Gothenburg

UK Segontium Roman Fort Caernarfon 77AD

St Asaph Cathedral 1601 - 04

Bevis Marks Synagogue London. (1701)

Buckingham Palace London C19 \& (C20)

Bodelwyddan Castle 1840

Custom House, Belfast 1856

Royal Pavilion, Brighton 1820

Downing College, Cambridge 1807 (2000)

Cathedral House, Glasgow

Covent Garden Market 1830

Penrhyn Castle 1827 - 1840

Roundhouse Camden 1990

Kings Cross Station 1852

British Library, London 1992

Welsh Assembly Building Cardiff, (flooring and cladding) C20

Welsh Assembly Building Llandudno (cladding) C21

National Waterfront Museum Swansea (walling) $\mathrm{C} 21$

Wales Millennium Centre (walling) C20

Jesus College, Cambridge C17 (C21)

USA The Shaker Museum, Enfield, New Hampshire Boston airport (flooring) late C20

West Indies The Red House, Trinidad 1907

\section{Related Heritage Issues}

The slate quarries and their associated tramway and later narrowgauge rail transport systems and network of local ports, stretching from north of Bethesda to the Nantlle valley are included in the 
proposed UNESCO World Heritage cultural landscape bid (Ref 5678 Submitted 27 January 2012).

The Welsh Slate Industry is a candidate World Heritage Site satisfying the following criteria:

- to exhibit an important interchange of human values, over a span of time or within a cultural area of the world, on developments in architecture or technology, monumental arts, town-planning or landscape design;

- to be an outstanding example of a traditional human settlement, land-use, or sea-use which is representative of a culture (or cultures), or human interaction with the environment especially when it has become vulnerable under the impact of irreversible change;

- the slate quarrying landscape of the Ogwen-Cegin valleys [Cambrian] comprising the Penrhyn quarry, its harbour at Port Penrhyn and associated rail system, and Penrhyn Castle, the home of the major quarry-owning family

- the Dinorwic quarry [Cambrian] with associated workings, innovative quarry hospital, worker settlements and transport systems, now part of the Welsh Slate Museum;

- Nantlle/Moel Tryfan [Cambrian] slate quarrying landscape with worker settlements and transport systems;

- the Gorsedda quarry, tramway and worker settlement;

- the Ffestiniog [Ordovician] slate landscape with early hydropower station and associated transport systems including the Ffestiniog Railway;

- the southern Gwynedd quarrying landscapes and transport systems; and

- the main university building at Bangor, reflecting the quarrymen's financial contribution to, and zeal for, education.

Welsh roofing slates have been used on thousands designated heritage buildings worldwide including most of those listed above

The National Slate Museum (National Museum Wales) at Llanberis is housed in the former Dinorwic Quarry workshops. It includes the timber mill, pattern shop, iron and brass foundry, forge, engineering workshop all powered by the original 15.4 metre diameter water wheel, narrow gauge railway and inclines, blondin quarry lifting gear, workmen's barracks and cottages and the workshop manager's house and quarry hospital. The industry's long history is displayed and slate making is demonstrated.

Examples of industrial innovation which have been conserved in situ in this area include: a Cornish beam engine, installed 1904-06 at the Dorothea Slate Quarry, Dyffryn Nantlle, and used for pumping water; the two water-balance shafts and headgear and the de Winton hydraulic lift pump at Penrhyn Quarry. A section of the narrow gauge railway from Penrhyn Quarry to Port Penrhyn has recently been reinstated by The Penrhyn Quarry Railway.

\section{Related Dimension Stones}

The Ordovician age slates quarried to the east of the Cambrian slates have a similar history, scale and extent of use. They will be the subject of a GHSR nomination proposal in the future. If accepted the two slate resources will be proposed as a Global World Heritage Province.

\section{Principle Literature}

- Lewis, 1924. Maritime Trade in Wales in Stuart Times, The Times Supplement: Industrial Wales, London.
- Pritchard, D. D., 1942 - 1944. Historical Aspects of the Welsh Slate Industry, Quarry Managers' Journal.

- North, M. J., 1925. The Slates of Wales, National Museum of Wales, Cardiff.

- Lindsey J., 1974. The History of the North Wales Slate Industry, Newton Abbot.

- Richards, A. J., 1991. A gazetteer of the Welsh Slate Industry, Llanberis.

- Hughes, T. G., 1995. The Slate Industry in Gwynedd, Gwynedd County Council, Caernarfon.

- Jones, R, M., 1982. The North Wales Quarrymen 1874 - 1922, Cardiff.

Websites

- http://www.slateroof.co.uk/Slate_industry.html

- http://www.museumwales.ac.uk/en/slate/

- http://www.welshslate.com/

- http://www.llechicymru.info/index.english.htm

\section{References}

Cooper, B.J. 2008, Recognition of a "World Heritage Stone Resource": A proposal. Abstracts 33rd International Geological Congress, Oslo, Norway, 6-14 August 2008 (compact disc reference only).

Cooper, B.J. 2010a, Toward establishing a "Global Heritage Stone Resource designation. Episodes, v.33, pp 38-41.

Cooper, B.J. 2010b, "Global Heritage Stone Resource": How can it be utilised to promote stone quarrying and stone projects?": Proceedings of the Global Stone Congress, Alicante (Spain) 2-5 March 2010 (compact disc reference only).

Cooper, B.J. 2010c, Recognising a "Global Heritage Stone Resource : Extended Abstracts to the Proceedings of the 11th Congress of the IAEG Auckland, New Zealand 5-10 September 2010 page 499.

Cooper, B.J., Marker, B.R., Pereira, D. and Schouenborg, B. 2013, Establishment of the "Heritage Stone Task Group" (HSTG). Episodes, v. 36 , pp. 8-10.

Evans, J.A., 1996. Dating the transition of smectite to illite in Palaeozoic mudrocks using the $\mathrm{Rb}-\mathrm{Sr}$ whole-rock technique. Journal of the Geological Society, London, v. 153, pp. 101-108.

GWP Consultants, February 2012, Penrhyn Quarry Realignment - Geological Statement for Welsh Slate Ltd. LLP

Howell, B.F. \& Stubblefield, C.J. 1950, A revision of the fauna of the North Welsh Conocorphye viola Beds, implying a Lower Cambrian age: Geological Magazine, v.87, pp. 1-16.

Hughes, T. G., 1995, The Slate Quarrying Industry in Gwynedd: Gwynedd County Council Economic Development and Planning Department.

Lewis, D. A., 1927, Welsh Port Books, 1550-1603, The Honorable Society of Cymmrodorion, London

Lindsey, J., 1974, The History of the North Wales Slate Industry, David \& Charles, Newton Abbot.

Munsell soil colour charts, 2000. Munsell colour, Grand Rapids, USA.

Manning, P.G., 1975. Mössbauer studies of the reduction spots in Welsh Purple Roofing Slates. Canadian Mineralogist, v. 13, pp. 358-360.

Meriman, R.J. 2005, From Mud to Roofing Slate: How Wales's Best-Known Building Stone was Formed: In Stone In Wales, Material, Heritage and Conservation., Cadw, Cardiff, pp 14-17.

Merriman, R.J. and Peacor, D.R., 1999, Very Low-grade Metapelites: Mineralogy, Microfabrics and Measuring Reaction Progress: In Frey, M. and Robinson, D. (Eds) Low-Grade metamorphism, Oxford: Blackwell Science Ltd., pp. 10-60.

North, F. J. 1925, The Slates of Wales: University of Wales, Cardiff.

Pritchard, D. D., 1942 - 1945, Articles in Quarry Manager's Journal, http:// www.slateroof.co.uk/Slate_industry.html 
Richards, A. J., 1991, A Gazetteer of the Welsh Slate Industry: Gwasg Garreg Gwalch, Llanrwst.

Richards, A. J., 2006, Slate Quarrying in Wales: Gwasg Garreg Gwalch, Llanrwst.

Rushton, A.W.A and Molyneux, S.G. 2011, Chapter 7, The Welsh basin, In Rushton, A.W.A, Brück, Molyneux, S.G. Williams, M. \& Woodcock, N.H.A. A Revised Correlation of the Cambrian Rocks in the British Isles. Geological Society of London Special Report, No. 2562 pp.

Sorbey, H.C. 1853, On the origin of salty cleavage: New Philosophical Journal of Edinburgh, v. 55, pp. 137-48.

Wheeler, R.E.M. 1923, Segontium and the Roman Occupation of Wales: Y Cymmrodor, p. 33.

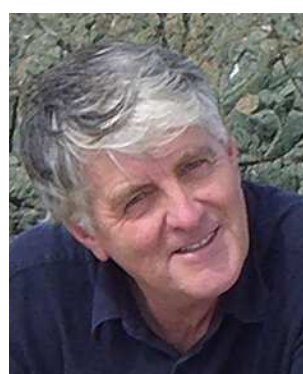

Terry Hughes, formerly technical manager at Penrhyn Quarry (Welsh Slate Ltd) was chairman of the European roofing slate technical committee and has represented the UK slating industry on other technical committees including the National Federation of Roofing Contractors and the British Standard Code of Practice for Slating and Tiling since 1983. He is chairman of the Stone Roofing Association, secretary of the English Stone Forum and a member of the Welsh Stone Forum. He has published extensively on slate and stone roofs and their UK regional variations and advised on their conservation for English Heritage and CADW Welsh Historic Monuments.

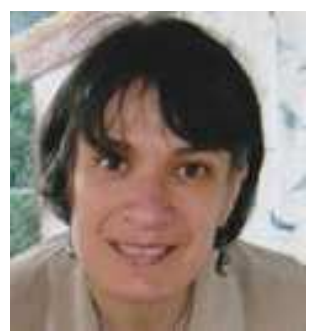

Jana Horák is Head of Mineralogy and Petrology at Amgueddfa Cymru National Museum Wales and holds a BSc and $\mathrm{PhD}$ in geology. She has expertise in the management and development of mineralogy and petrology collections and her geological research includes the early evolution of Avalonia from the Neoproterozoic to early Palaeozoic. She is secretary of the Welsh Stone Forum and has also worked extensively on the petrology and provenance of stone used in historic contexts in Wales including the petrology of Neolithic axes, building and sculptural use of medieval stone and the documentation and characterisation of more recently worked lithologies.
Wood, D.S., 1971, Current views on the development of slaty cleavage: Review of Earth and Planetary Science, v. 88, pp. 285-401.

\section{Referenced websites}

Slateroof.co.uk http://www.slateroof.co.uk/Slate_industry (accessed 16 July 2013)

UNESCO World Heritage Centre - Official site: World Heritage Nomination - IUCN technical evaluation Dorset and East Devon Coast (United Kingdom) http://whc.unesco.org/ (accessed 12 October 2010).

UNESCO World Heritage List - Castles and Town Walls of King Edward in Gwynedd http://whc.unesco.org/en/list/374 (accessed 22 March 2014).

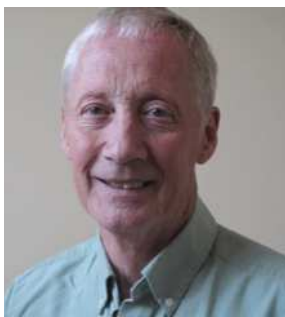

Graham Lott, formerly Senior Geologist/ Sedimentary Petrographer with the British Geological Survey (BGS), has a long standing interest in the geology and petrography of UK building stones and their historic use throughout the UK. He has collaborated with all the major UK heritage organisations to promote an understanding of the geological context of the stones and their traditional use. He is a committee member of the English Stone Forum and was co-ordinator and contributor to the English Heritage/BGS Strategic Stone Study to source and characterise the principal building stone used in England.

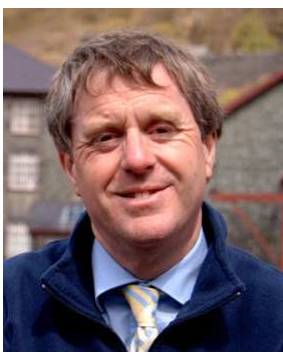

Dafydd Roberts is Keeper of Amgueddfa Lechi Cymru/National Slate Museum, part of Amgueddfa Cymru/National Museum Wales. His University of Wales $\mathrm{PhD}$ assessed the social history of the slate quarrying communities during the twentieth century. He has broadcasted, lectured and published extensively on the history and sociology of the Welsh slate industry. He is part of the Gwynedd Council-led team which is developing a World Heritage Bid for the slate areas within the county. 